\title{
JUAL BELI TANAH TANPA MENGGUNAKAN AKTA PEJABAT PEMBUAT AKTA TANAH (STUDI PUTUSAN MAHKAMAH AGUNG NOMOR: 153 PK/PDT/2005)
}

\author{
Adi Gunawan \\ Program Studi Kenotariatan Fakultas Hukum Universitas Lambung Mangkurat.Jln. \\ Brigjen H. Hasan Basri 70123 Banjarmasin, Indonesia Tel: 05113307877, E-Mail: Adi_ \\ gunawan2214@yahoo.co.id
}

Submitted: 10/01/2017; Reviewed:29/03/2017; Accepted: 30/03/2017

Abstract:The goal of this research is to know and analyze the status of sale and purchase of land performed without using the deed of Land Deed Making Official (PPAT), especially the verdict of the Supreme Court Number: 153 PK/PDT/2005 and to know analyze whether the transfer of land right at Land Office for sale and purchase of land right without using the deed of Land Deed Making Official (PPAT) is possible or not. It is expected that this research can be used as reference and additional reading material. This research is normative legal research and its type is legal syncronization. The result of the research for the first issue is that the status of sale and purchase of land performed without using deed of Land Deed Making Official (PPAT), especially the verdict of the Supreme Court Number: 153 PK/PDT/2005 is the said sale and purchase is stipulated legal by the Court, but the Panel of Judges still instructed/punished the seller and the buyer to appear before the Land Deed Making Official (PPAT) in order to make the Deed of Sale and Purchase because sale and purchase of certificated land must be performed before the Land Deed Making Official (PPAT). The result of the research for the second issue is that the sale and purchase of land performed without using the deed of Land Deed Making Official (PPAT) can perform transfer of land right at Land Office, but this matter is only valid for remote areas where there are no Land Deed Making Official (PPAT) and temporary Land Deed Making Official (PPAT) heve not yet been appointed.

Keywords: Deed of Land Deed Making Official; Sale and Purchase; Verdict of Suprime Court Number: 153 PK/PDT/2005

Abstrak:Tesis ini berjudul Jual Beli Tanah Tanpa Menggunakan Akta Pejabat Pembuat Akta Tanah (Studi Putusan Mahkamah Agung Nomor: 153 PK/PDT/2005). Tujuan dari penelitian ini adalah untuk mengetahui dan menganalisis status jual beli 
tanah yang dilakukan tanpa menggunakan akta Pejabat Pembuat Akta Tanah (PPAT) khususnya pada Putusan Mahkamah Agung Nomor: 153 PK/PDT/2005) dan untuk mengetahui dan menganalisis dapat tidaknya pendaftaran hak atas tanah di Kantor Pertanahan untuk jual beli hak atas tanah tanpa akta Pejabat Pembuat Akta Tanah. Kegunaan dari penelitian ini diharapkan dapat digunakan sebagai referensi atau bahan bacaan tambahan. Jenis penelitian yang digunakan adalah penelitian hukum normatif dan tipe penelitian sinkronisasi hukum. Menurut hasil penelitian terhadap rumusan masalah yang pertama yaitu status jual beli tanah tanpa menggunakan akta Pejabat Pembuat Akta Tanah (Studi Putusan Mahkamah Agung Nomor: 153 PK/PDT/2005) adalah jual belinya dinyatakan sah oleh Pengadilan, tetapi Majelis Hakim tetap memerintahkan/menghukum penjual dan pembeli menghadap Pejabat Pembuat Akta Tanah untuk membuat Akta Jual Beli. Karena jual beli untuk tanah bersertifikat harus dilakukan di hadapan Pejabat Pembuat Akta Tanah. Menurut hasil penelitian terhadap rumusan masalah yang kedua yaitu jual beli tanah tanpa menggunakan akta Pejabat Pembuat Akta Tanah dapat melakukan pendaftaran peralihan hak atas tanah di Kantor Pertanahan, namun hal ini hanya berlaku untuk daerah-daerah terpencil yang belum mempunyai Pejabat Akta Tanah dan belum ditunjuknya Pejabat Pembuat Akta Tanah Sementara.

Kata kunci: Akta PPAT; Jual Beli; Putusan Mahkamah Agung Nomor:153PK/PDT/2005

\section{PENDUHULUAN}

Tanah adalah bagian dari permukaan bumi paling atas yang merupakan tempat manusia hidup dan berkembang, tanah menjadi segala sumber bagi segala kepentingan manusia. Demikian pentingnya tanah bagi kehidupan manusia, karenanya tidak mengherankan kalau setiap manusia ingin memiliki dan menguasainya. Banyaknya jumlah manusia yang ingin menguasai dan memiliki tanah tidak sebanding dengan jumlah luas tanah yang sangat terbatas, sehingga berakibat timbulnya masalah-masalah tanah. Saat ini, untuk memperoleh tanah dapat diperoleh dengan beberapa cara, yaitu dengan permohonan hak, pemindahan hak, perolehan hak atas tanah lebih sering dilakukan dengan pemindahan hak, yaitu dengan melalui jual beli. Karena banyaknya orang yang membutuhkan tanah menyebabkan harga tanah semakin lama semakin naik harganya, sehingga harga tanah semakin lama semakin tinggi, hal ini juga menyebabkan sebagian masyarakat menganggap bahwa membeli tanah adalah investasi yang bagus, bahkan lebih menguntungkan dari pada menabung.

Perjanjian jual beli adalah suatu perjanjian dimana pihak yang satu menyanggupi akan menyerahkan hak milik atas suatu barang,sedang pihak lain

menyanggupi akan membayar sejumlah uang sebagai harganya. Dalam KUH-

Perdata Pasal 1457, jual beli adalah suatu perjanjian dengan mana penjual mengikatkan dirinya untuk menyerahkan suatu barang, dan pihak yang lain untuk membayar harga yang dijanjikan.

Menurut obyeknya jual beli dibedakan 
menjadi dua, yaitu jual beli terhadap benda bergerak dan benda tidak bergerak. Jual beli terhadap benda bergerak, penyerahannya secara nyata dan penyerahan yuridis dilakukan pada saat bersamaan, artinya dengan dilakukannya penyerahan fisik atas benda itu, maka ketika itu telah berpindah hak milik atas benda itu dan tidak diperlukan akta penyerahan, cukup dilakukan secara dari tangan ke tangan. Sedangkan untuk jual beli benda tidak bergerak, tidak cukup dilakukan hanya penyerahan secara nyata kekuasaan atau fisik atas benda tersebut tetapi yang menentukan perpindahan hak milik atas benda itu adalah pada penyerahan secara yuridis yang dilakukan yaitu dengan cara membuat akta penyerahan dan didaftar di lembaga pendaftaran yang diperuntukan untuk itu, misalnya dalam hal ini adalah tanah dilakukan pendaftran untuk merubah status kepemilikan hak di Badan Pertanahan Nasional. Maka dalam hal ini jual beli tanah berbeda dengan jual beli benda yang lain.

Pada saat Negara Indonesia merdeka, hukum tanah di Indonesia masih mengandung corak "dualisme" dimana peraturan-peraturan agraria terdiri dari hukum barat dan hukum adat. Maka dibuatlah Undang-Undang Nomor 5 Tahun 1960 tentang Peraturan Dasar Pokok-pokok Agraria sebagaimana yang dimuat dalam Lembaran Negara Nomor 104, Tahun 1960 yang lebih dikenal dengan Undang-Undang Pokok Agraria (UUPA).

Dengan adanya Undang-Undang Pokok Agraria (UUPA), maka berakhirlah dualisme didalam hukum agraria Indonesia dan terselenggaralah unifikasi hukum. Hukum agraria yang baru tidak lagi terdiri atas peraturan-peraturan yang bersumber dari hukum adat dan peraturan-peraturan yang bersumber pada hukum barat. Hukum agraria nasional kita selanjutnya didasarkan atas satu sistem hukum, yaitu hukum adat, sebagai hukum asli Indonesia.

Dalam Pasal 5 Undang-Undang Pokok Agraria yang berbunyi: "Hukum Agraria yang berlaku atas bumi, air dan ruang angkasa ialah Hukum Adat sepanjang tidak bertentangan dengan kepentingan nasional dan negara yang berdasarkan atas persatuan bangsa, dengan sosialisme bangsa dan peraturan-peraturan yang tercantum dalam Undang-Undang ini dan dengan peraturan perundangan lainnya, segala sesuatu dengan mengindahkan unsurunsur yang bersandar pada Hukum Agama”. Ketentuan ini memuat penegasan bahwa Hukum Adat dijadikan dasar dari pada Hukum Agraria Nasional dengan diberikan beberapa pembatasan.

Menurut hukum adat yang sebagai dasar dari Undang-Undang Pokok Agraria, jual beli tanah bukan merupakan perjanjian yang dimaksudkan dalam Pasal 1457 KUHPerdata, melainkan suatu perbuatan hukum yang berupa penyerahan tanah yang bersangkutan oleh penjual kepada pembeli untuk selama-lamanya pada saat mana pihak pembeli menyerahkan harganya kepada penjual. Selanjutnya diatur dalam Peraturan Pelaksanaan dari Undang-Undang Pokok Agraria yaitu Peraturan Pemerintah Nomor 10 Tahun 1961 yang telah diperbaruhi dengan Peraturan Pemerintah Nomor 24 Tahun 1997, tentang Pendaftaran Tanah, yang menentukan bahwa jual beli tanah harus dibuktikan dengan suatu akta yang dibuat oleh dan di hadapan Pejabat Pembuat Akta Tanah (PPAT), sebagaimana yang telah dinyatakan secara tegas dalam ketentuan Pasal 37 ayat (1) Peraturan Pemerintah Nomor 24 Tahun 1997 yang berbunyi: "Peralihan hak atas tanah dan hak milik atas satuan rumah susun melalui jual beli, tukar-menukar, hibah, pemasukan 
data perusahaan dan perbuatan hukum pemindahan hak lainnya, kecuali pemindahan hak melalui lelang hanya dapat didaftarkan jika dibuktikan dengan akta yang dibuat oleh Pejabat Pembuat Akta Tanah (PPAT) yang berwenang menurut ketentuan peraturan perundang-undangan yang berlaku".

Peraturan Pemerintah Nomor 37 Tahun 1998, tentang Peraturan Pejabat Pembuat Akta Tanah (PPAT) dalam Pasal 2 ayat (1) yang berbunyi sebagai berikut: "Pejabat Pembuat Akta Tanah (PPAT) bertugas pokok melaksanakan sebagian kegiatan pendaftaran tanah dengan membuat akta sebagai bukti telah dilakukannya perbuatan hukum tertentu mengenai hak atas tanah atau Hak Milik Atas Satuan Rumah Susun yang akan dijadikan dasar bagi pendaftaran perubahan data pendaftaran tanah yang diakibatkan oleh perbuatan hukum itu".

Maka dapat diartikan bahwa jual beli Hak atas Tanah harus dilakukan dihadapan Pejabat Pembuat Akta Tanah (PPAT), sebagai bukti bahwa telah terjadi perbuatan hukum jual beli hak atas tanah dan setelah itu dapat didaftarkan ke Kantor Pertanahan setempat selambat-lambatnya tujuh hari kerja sejak ditandatanganinya akta. Tetapi pada kenyataannya, pada saat ini masih banyak jual beli tanah yang dilakukan tidak menggunakan akta Pejabat Pembuat Akta Tanah atau sering disebut "Jual beli di bawah tangan", yang biasanya hanya dibuat dengan selembar kwitansi atau di atas kertas bermaterai. Jual beli seperti ini akan menimbulkan masalah dikemudian hari, seperti kasus yang terjadi di Kabupaten Semarang. Hal ini bertentangan dengan Pasal 19 PP No. 10 Tahun 1961 yang disempurnakan dengan Peraturan Pemerintah No. 24 Tahun 1997 Tentang Pendaftaran Tanah yang menyatakan bahwa setiap peralihan hak atas tanah harus dibuat di hadapan Pejabat Pembuat Akta Ta- nah, karena jual beli yang dilakukan di bawah tangan tidaklah dapat didaftarkan.

\section{METODE}

Jenis penelitian yang digunakan oleh peneliti adalah Penelitian Hukum Normatif, penelitian ini dilakukan dengan penelitian kepustakaan, menggunakan tiga bahan hukum yaitu bahan hukum primer, bahan hukum sekunder dan bahan hukum tersier. Penelitian menggunakan Studi Putusan Mahkamah Agung Nomor: 153 PK/PDT/2005. Tipe penelitian yang peneliti pergunakan dalam penelitian ini adalah tipe penelitian terhadap sinkronisasi hukum tentang Peraturan Pemerintah Nomor 24 Tahun 1997 dengan Hukum Adat berkaitan dengan Putusan Mahkamah Agung Nomor 153 PK/PDT/2005. Pendekatan yang dilakukan dalam penelitian ini yaitu menggunakan pendekatan kasus, dengan melakukan inventarisasi terhadap ketentuan mengenai jual beli tanah serta mengenai pendaftaran tanah.

Penelitian ini bersifat Preskriptif analitis. Dikatakan Preskriptif, karena penelitian ini memberikan Preskripsi mengenai apa yang seyogyanya mengenai segala hal yang berhubungan dengan jual beli tanah tanpa menggunakan akta Pejabat Pembuat Akta Tanah (PPAT) dan pendaftaran tanah.

\section{ANALISIS DAN PEMBAHASAN Jual Beli Secara Umum}

Menurut Pasal 1457 KUH Perdata, yang dimaksud dengan jual beli adalah suatu perjanjian, dengan mana pihak yang satu mengikatkan dirinya untuk menyerahkan suatu kebendaan dan pihak yang lain untuk membayar harga yang telah dijanjikan. Dengan kata lain jual beli merupakan suatu bentuk perjanjian yang melahirkan kewajiban atau perikatan untuk menberikan sesuatu, yang 
dalam hal ini bentuk penyerahan kebendaan yang dijual oleh penjual, dan penyerahan uang oleh pembeli kepada penjual. Dengan demikian perkataan jual beli ini menunjukan bahwa dari satu pihak perbuatan dinamakan menjual, sedangkan dari pihak lain dinamakan pembeli, jadi dalam hal ini terdapat dua pihak yaitu penjual dan pembeli yang bertimbal balik..

Dalam perjanjian jual beli yang terdapat penjual dan pembeli memiliki hak dan kewajiban yang bertimbal balik dimana bagi si penjual berkewajiban untuk menyerahkan hak milik atas barang yang diperjual belikan serta menjamin kenikmatan tenteram atas barang tersebut dan menanggung atas barang tersebut dan menanggung terhadap cacatcacat yang tersembunyi dan terhadapnya berhak untuk menerima pembayaran harga yang berupa sejumlah uang pada saat pembelian pada waktu dan ditempat sebagaimana yang ditetapkan menurut perjanjian, sedangkan haknya adalah menerima barang yang diperjual belikan dari penjual tersebut.

\section{Teori Kesepakatan}

Kesepakatan atau konsensus merupakan langkah awal dari para pihak yang membuat suatu perjanjian. Jika kesepakatan itu merupakan langkah awal dari para pihak yang membuat perjanjian maka timbul suatu permasalahan mengenai kapan saat terjadinya kesepakatan tersebut. Ada beberapa teori yang menyatakan terjadinya kesepakatan. Teori-teori itu adalah:

1. Teori Kehendak (Wills Theory), Menurut teori ini, faktor yang menentukan adanya perjanjian adalah kehendak. Meskipun demikian, terdapat hubungan yang tidak terpisahkan antara kehendak dan pernyataan. Oleh karena itu suatu kehendak harus dinyatakan. Namun apabila terdapat ketidak sesuaian antara kehendak dan pernyataan, maka tidak terbentuk suatu perjanjian.

2. Teori Pernyataan (Verklaringstheorie), teori ini berpendapat bahwa pembentukan kehendak adalah proses yang terjadi dalam ranah kejiwaan seseorang (innerlijke proces). Sehingga pihak lawan tidak mungkin mengetahui apa yang sebenarnya berlangsung di dalam benak seseorang. Dengan demikian suatu kehendak yang tidak dapat dikenal oleh pihak luar tidak mungkin menjadi dasar terbentuknya perjanjian. Agar suatu kehendak dapat menjadi perjanjian, maka kehendak itu harus dinyatakan.

3. Teori kepercayaan (Vertrouweng Theory), teori ini beranjak dari teori pernyataan, tetapi diperlunak. Tidak semua pernyataan melahirkan perjanjian. Pernyataan yang melahirkan perjanjian hanyalah pernyataan kepada pihak lain yang menurut kebiasan di dalam masyarakat menimbulkan kepercayaan bahwa hal yang dinyatakan memang benar dikehendaki.

\section{Jual Beli Menurut Undang-Undang Pokok Agraria}

Jual beli menurut Undang-Undang Pokok Agraria dapat dilihat dari dasar pembentukan Undang-Undang No. 5 Tahun 1960 (Hukum Agraria Nasional), yaitu didasarkan atas hukum adat, sebagaimana disebutkan dalam Pasal 5-nya yaitu: "Hukum agraria yang berlaku atas bumi, air, dan ruang angkasa ialah hukum adat, sepanjang tidak bertentangan dengan kepentingan nasioanal dan Negara, yang berdasarkan atas persatuan bangsa, 
dengan sosialisme Indonesia serta dengan peraturan-peraturan yang tercantum dalam undang-undang ini dan dengan peraturan perundang-undangan yang lainnya, segala sesuatu dengan mengindahkan unsur-unsur yang bersandar pada hukum agama". Dengan demikian hukum agraria didasarkan atas hukum adat yang disesuaikan dengan asasasas yang ada dalam Undang-Undang Pokok Agraria, karena dalam Undang-Undang Pokok Agraria menganut sistem dan asas hukum adat maka perbuatan jual beli tersebut adalah merupakan jual beli riil dan tunai.

Pada saat ini jual beli tanah tidak lagi dilakukan dihadapan Kepala Desa saja karena setiap peralihan hak atas tanah harus dilakukan dihadapan pejabat yang ditunjuk oleh Menteri Agraria seperti dalam Pasal 37 Peraturan Pemerintah Nomor 24 tahun 1997. Pejabat yang dimaksud adalah Pejabat Pembuat Akta Tanah. Dilakukan jual beli tanah dihadapan pejabat yang ditunjuk oleh Menteri Agraria tersebut, maka jual beli itu selesai, dan selanjutnya peralihan hak atas tanah tersebut didaftarkan ke Kantor Pertanahan untuk menjamin kepastian hukum. Hal ini sesuai dengan ketentuan Undang-Undang Pokok Agraria Pasal 23 yang menyebutkan:

1. Hak milik demikian pula setiap peralihan hapusnya pembebanannya dengan hakhak lain harus didaftarkan menurut ketentuan-ketentuan yang dimaksud dalam Pasal 19.

2. Pendaftaran termaksud dalam ayat 1 merupakan alat pembuktian yang kuat mengenai hapusnya hak milik serta sahnya peralihan dan pembebanan hak tersebut.

Beralihnya hak menurut Effendi Perangin adalah: Jual beli yang tidak dilakukan dihadapan Pejabat Pembuat Akta Tanah tidak akan melahirkan jual beli, paling jauh baru menimbulkan perjanjian akan jual beli, yang masih perlu diikuti dengan jual beli yang sebenarnya, yang harus dilakukan di muka Pejabat Pembuat Pembuat Akta Tanah, jika memang dikehendaki bahwa haknya akan beralih kepada pihak yang telah membayar harga tanahnya. Dapatlah kita katakan, bahwa saat beralihnya hak milik dari penjual kepada pembeli, ialah ketika dilakukan jual beli dihadapan Pejabat Pembuat Akta Tanah.

\section{Syarat-Syarat Jual Beli Tanah}

Syarat-syarat dalam perbuatan hukum terhadap pengalihan hak atas tanah terbagi menjadi dua macam, yaitu:

a. Syarat Materiil

Syarat materiil sangat menentukan akan sahnya jual beli tanah tersebut, antara lain sebagai berikut:

1. Penjual adalah orang yang berhak atas tanah yang dijualnya.

2. Pembeli adalah orang yang berhak untuk mempunyai hak atas tanah yang dibelinya. Tanah yang bersangkutan boleh diperjualbelikan atau tidak dalam sengketa.

Jika salah satu syarat materiil ini tidak dipenuhi, atau dikatakan penjual bukan merupakan orang yang berhak atas tanah yang dijualnya atau pembeli tidak memenuhi syarat untuk menjadi pemilik hak atas tanah menurut Undang-Undang atau tanah yang diperjual belikan sedang dalam sengketa atau merupakan tanah yang tidak boleh diperjual belikan, maka jual beli tanah tersebut tidak sah.

b. Syarat Formal

Setelah semua persyaratan materiil tersebut terpenuhi, maka dilakukan jual beli dihadapan Pejabat Pembuat Akta Tanah. 


\section{Analisis Putusan Mahkamah Agung No- mor: 153/PK/PDT/2005}

Pada kasus perkara dalam Putusan Pengadilan Nomor 44/Pdt.G/2002/PN.Ung, yang pada Putusan Peninjauan Kembali Nomor 153/PK/PDT/2005, jual beli tanah antara Isak Susilo Santoso (pembeli) dengan Widayat Soetejo (penjual) Sertifikat HM No.63 atas nama Widayat Soetejo, mereka bersepakat dan membuat perjanjian akan melakukan jual beli dihadapan Pejabat Pembuat Akta Tanah (PPAT), namun sebelum menghadap Pejabat Pembuat Akta Tanah (PPAT) mereka terlebih dahulu melakukan jual beli secara di bawah tangan pada tanggal 1 Desember 1984 yang dilakukan dihadapan Lurah Candirejo Kecamatan Ungaran Kabupaten Semarang dan dibayar tunai tetapi sertifikat belum diserahkan oleh Widayat Soetejo. Pada hari yang telah disepakati mereka berdua akan melakukan jual beli dihadapan Pejabat Pembuat Akta Tanah, namun ternyata Widayat Soetejo tidak dapat melaksanakan atau memenuhinya, karena Sertifikat HM No.63 tersebut berada di tangan Adi Martanto Bintoro sebagai jaminan utang (pinjam meminjam), bahkan sertifikat tersebut sudah dijual oleh Adi Martanto Bintoro kepada A. Rudhy Arto S. BA. Isak Susilo Santoso melakukan gugatan ke Pengadilan Negeri dan dimenangkan oleh Isak Susilo Santoso dan gugatan penggugat dikabulkan oleh Majelis Hakim, yang mana Majelis Hakim menyatakan sah dan berharga surat pernyataan tanggal 1 Desember 1984 dan berita acara jual beli tanah pekarangan tanggal 1 Desember 1984 serta pada poin ketiga dalam Amar Putusan, Majelis Hakim menyatakan jual beli tanah sengketa bersertifikat HM No.63 atas nama Widayat Soetejo antara Penggugat dengan Tergugat I adalah sah menurut hukum, tetapi Majelis Hakim tetap menghukum Tergugat I untuk bersama-sama Penggugat untuk menghadap Pejabat Pembuat Akta Tanah (PPAT) untuk membuat akta tanah atau Akta Jual Beli. Karena untuk jual beli tanah yang bersertifikat harus dilakukan di hadapan Pejabat Pembuat Akta Tanah.

Jual beli tanah adalah sah secara hukum apabila semua syarat materiil dan syarat formal terpenuhi dan unsur-unsur teori kesepakatan terpenuhi karena dalam jual beli tersebut para pihak memiliki kehendak kemudian membuat pernyataan untuk melakukan jual beli berdasarkan kepercayaan antara para pihak.

Jual beli tanah dengan cara di bawah tangan atau yang tidak dilakukan di hadapan Pejabat Pembuat Akta Tanah tidak dapat didaftarkan pada Kantor Pertanahan, karena dalam Peraturan Pemerintah Nomor 24 Tahun 1997 Tentang Pendaftaran Tanah yaitu pada Pasal 37 secara tegas menyebutkan: "Peralihan hak atas tanah dan hak milik satuan rumah susun melalui jual beli, tukar menukar, hibah, pemasukan data perusahaan dan perbuatan hukum pemindahan hak lainnya, kecuali pemindahan hak melalui lelang hanya dapat didaftarkan jika dibuktikan dengan akta yang dibuat oleh Pejabat Pembuat Akta Tanah yang berwenang menurut ketentuan peraturan perundang-undangan yang berlaku".

Pasal ini dengan tegas menyebutkan bahwa peralihan hak tanpa menggunakan akta Pejabat Pembuat Akta Tanah tidak akan diterima pendaftarannya. Sehingga jual beli tanah tanpa menggunakan akta Pejabat Pembuat Akta Tanah berdampak kepada pihak pembeli yang tidak dapat melakukan balik nama sertifikat tanah di Kantor Pertanahan setempat, sehingga si pembeli tidak mempunyai kepastian hukum karena nama yang tercantum dalam sertifikat masih atas nama 
pemilik yang lama atau nama si penjual.

\section{Pendaftaran Tanah}

Undang-Undang Pokok Agraria mengatur pendaftaran tanah yang bertujuan memberikan jaminan kepastian hukum. Pendaftaran tanah ini menjadi kewajiban bagi Pemerintah maupun pemegang hak atas tanah. Ketentuan tentang kewajiban Pemerintah untuk menyelenggarakan pendaftaran tanah diseluruh wilayah Republik Indonesia diatur dalam Pasal 19 ayat 1 Undang-Undang Pokok Agraria, yaitu:

"Untuk menjamin kepastian hukum oleh Pemerintah diadakan pendaftaran tanah di seluruh wilayah Republik Indonesia menurut ketentuan-ketentuan yang diatur dengan Peraturan Pemerintah".

Pendaftaran tanah untuk pertama kali adalah kegiatan pendaftaran tanah yang dilakukan terhadap obyek pendaftaran tanah yang belum didaftar berdasarkan Peraturan Pemerintah Nomor 10 Tahun 1961 Tentang Pendaftaran Tanah atau Peraturan Pemerintah Nomor 24 Tahun 1997 Tentang Pendaftaran Tanah. Kegiatan pendaftaran tanah untuk pertama kali dilakukan dengan dua cara:

a. Pendaftaran tanah secara sistematik Pendaftaran tanah secara sistematik adalah kegiatan pendaftaran tanah untuk pertama kali yang dilakukan secara serentak yang meliputi semua obyek pendaftaran tanah yang belum didaftar dalam wilayah atau bagian wilayah suatu Desa/Kelurahan, dengan kata lain, pendaftaran tanah tersebut didasarkan pada suatu rencana kerja dan dilaksanakan di suatu wilayah dengan inisiatif pelaksanaan berasal dari Pemerintah.

b. Pendaftaran tanah secara sporadik
Pendaftaran tanah secara sporadik adalah kegiatan pendaftaran tanah untuk pertama kali mengenai satu atau beberapa obyek pendaftaran tanah dalam wilayah atau bagian wilayah suatu Desa/Kelurahan secara individual atau massal, dengan kata lain, pendaftaran tanah tersebut hanya atas satu bidang tanah yang dilakukan atas permintaan pihak yang berkepentingan.

Meskipun Undang-Undang Pokok Agraria mengatur pendaftaran tanah, namun tidak memberikan pengertian apa yang dimaksud dengan pendaftaran tanah. Begitu pula dengan Peraturan Pemerintah Nomor 10 Tahun 1961 tentang Pendaftaran Tanah, juga tidak memberikan apa yang dimaksud dengan pendaftaran tanah. Baru setelah dimuat dalam Pasal 1 angka 1 Peraturan Pemerintah Nomor 24 tahun 1997 terdapat pengertian tentang Pendaftaran Tanah. Pendaftaran Tanah adalah "rangkaian kegiatan Pemerintah yang dilakukan secara terus menerus, berkesinambungan dan teratur meliputi pengumpulan, pengolahan, pembukuan dan penyajian serta pemeliharaan data fisik dan data yurudis dalam bentuk peta dan daftar mengenai bidang tanah dan satuan rumah susun termasuk pemberian surat tanda bukti dalam bentuk peta dan daftar menegenai bidang tanah dan satuan rumah susun termasuk pemberian surat tanda bukti haknya bagi bidang-bidang tanah yang sudah ada haknya dan hak milik satuan rumah susun serta hak-hak tertentu yang membebaninya".

Banyaknya maanfaat sekaligus permasalahan yang timbul dan bersumber dari kepemilikan hak atas tanah. Untuk mengantisipasi segala bentuk perselisihan yang mungkin terjadi, maka oleh Undang-Undang pemilik hak wajib mendaftarkan tanah yang menjadi haknya, agar tidak terjadi sesuatu yang meru- 
gikan dikemudian hari.

\section{Pendaftaran Peralihan Hak Atas Tanah}

Menurut Pasal 1 angka 1 Peraturan Pemerintah Nomor 24 Tahun 1997, yang dimaksud dengan pendaftaran tanah adalah serangkaian kegiatan yang dilakukan oleh Pemerintah secara terus-menerus, berkesinambungan dan teratur, meliputi pengumpulan, pengolahan, pembukuan, dan penyajian serta pemeliharaan data fisik dan data yuridis, dalam bentuk peta dan daftar mengenai bidang-bidang tanah dan satuan-satuan rumah susun, termasuk pemberian surat tanda buktinya bagi bidang-bidang yang sudah ada haknya dan hak milik atas satuan rumah susun serta hak-hak tertentu yang membebaninya.

Peralihan hak atas tanah karena jual beli, menurut Pasal 37 Peraturan Pemerintah Nomor 24 Tahun 1997, hanya dapat didaftarkan apabila dibuktikan dengan akta yang dibuat oleh Pejabat Pembuat Akta Tanah yang berwenang. Sudah tentu bahwa untuk memperlancar pelaksanaan pendaftaran tanah, Kepala Kantor Pertanahan dibantu oleh Pejabat Pembuat Akta Tanah dan pejabat lain yang ditugaskan untuk melaksanakan kegiatan-kegiatan tertentu. Peraturan Pemerintah Nomor 24 Tahun 1997 tentang Pendaftaran Tanah telah ditetapkan jabatan Pejabat Pembuat Akta Tanah (PPAT) yang diberikan kewenangan untuk membuat alat bukti mengenai perbuatan hukum tertentu mengenai hak atas tanah dan hak milik atas satuan rumah susun yang akan dijadikan dasar pendaftaran tanah. Seperti yang disebutkan dalam Pasal 1 angka 24 Peraturan Pemerintah Nomor 24 Tahun 1997 memberikan defenisi tentang Pejabat Pembuat Akta Tanah (PPAT) adalah: "Pejabat umum yang diberi kewenangan untuk membuat akta-akta tanah tertentu". Dan dalam Pasal 1 ayat 1 Peraturan Pemerintah Nomor 37 Tahun 1998 tentang Peraturan Jabatan Pejabat Pembuat Akta Tanah yang berbunyi: "Pejabat Pembuat Akta Tanah, selanjutnya disebut PPAT, adalah Pejabat umum yang diberikan kewenangan untuk membuat akta-akta otentik mengenai perbuatan hukum tertentu mengenai hak atas tanah dan Hak Milik Atas Satuan Rumah Susun”.

Tugas Pokok Pejabat Pembuat Akta Tanah diatur dalam Pasal 2 Peraturan Pemerintah Nomor 37 Tahun 1998, yaitu melaksanakan sebagian kegiatan pendaftaran tanah dengan membuat akta sebagai bukti telah dilakukannya perbuatan hukum tertentu mengenai Hak atas Tanah dan Hak Milik atas Satuan Rumah Susun yang akan dijadikan dasar bagi pendaftaran perubahan data pendaftaran tanah yang diakibatkan oleh perbuatan hukum itu, perbuatan hukum yang dimaksud adalah
a. Jual Beli
b. Tukar Menukar;
c. Hibah
d. Pembagian Hak Bersama
e. Pembagian Hak Guna Bangunan/Hak Pakai atas Tanah Hak Milik
f. Pemberian Hak Tanggungan
g. Pemberian Kuasa Membebankan Hak Tanggungan

\section{Pendaftaran Peralihan Hak KarenaJual Beli Tanpa Menggunakan Akta Pejabat Pembuat Akta Tanah}

Perbuatan hukum berupa jual beli, hibah, tukar menukar, pemasukan dalam modal perusahaan (inbreng) dibuktikan dengan akta yang dibuat oleh Pejabat Pembuat Akta Tanah (PPAT), sedangkan perbuatan hukum berupa lelang dibuktikan dengan dengan Berita Acara atau Risalah Lelang yang dibuat 
oleh pejabat dari Kantor Lelang.

Untuk daerah yang belum, mempunyai atau masih kekurangan Pejabat Pembuat Akta tanah maka ditunjuklah Pejabat Pembuat Akta Tanah Sementara yang biasanya dijabat oleh Camat/Kepala Desa, seperti disebutkan dalam Peraturan Pemerintah Nomor 24 Tahun 1997 Pasal 7,yaitu:

1. Pejabat Pembuat Akta Tanah sebagaimana dimaksud dalam Pasal 6 ayat (2) diangkat dan diberhentikan oleh Menteri.

2. Untuk desa-desa dalam wilayah yang terpencil Menteri dapat menunjuk Pejabat Pembuat Akta Tanah sementara.

3. Peraturan jabatan Pejabat Pembuat Akta Tanah sebagaimana dimaksud pada Ayat (1) diatur dengan Peraturan Pemerintah.

Dalam keadaan tertentu Jual beli secara di bawah tangan atau jual beli tanpa menggunakan akta Pejabat Pembuat Akta dapat didaftarkan ke Kantor Pertanahan, hal ini disebutkan dalam Peraturan Pemerintah nomor 24 Tahun 1997 Pasal 37 ayat 2, yang berbunyi: Dalam keadaan tertentu sebagaimana yang ditentukan oleh Menteri, Kepala Kantor Pertanahan dapat mendaftar pemindahan hak atas bidang tanah hak milik, yang dilakukan di antara perorangan warga Negara Indonesia yang dibuktikan dengan akta yang tidak dibuat oleh Pejabat Pembuat Akta Tanah, tetapi yang menurut Kepala Kantor Pertanahan tersebut kadar kebenarannya dianggap cukup untuk, mendaftar pemindahan hak yang bersangkutan.

Boedi harsono menjelaskan tentang bunyi Pasal tersebut, yaitu pengecualian dari pada ayat 1 (satu) perlu diberikan dalam keadaan tertentu yaitu untuk daerah-daerah yang terpencil dan belum ditunjuk Pejabat
Pembuat Akta Tanah Sementara sebagaimana dimaksud dalam Pasal 7 ayat 2, untuk memudahkan rakyat melaksanakan perbuatan hukum mengenai tanah.

Terkait dengan Pasal tersebut, sangat dimungkinkan jual beli tanpa menggunakan akta Pejabat Pembuat Akta Tanah atau yang biasanya disebut jual beli di bawah tangan, dapat melakukan pendaftaran perallihan haknya di Kantor Pertanahan. Asalkan jual beli tersebut dilakukan dan letak obyek jual beli/tanah yang dijual dalam wilayah/keadaan tertentu dan dengan bukti yang menurut Kepala Kantor Pertanahan kadar kebenaranya cukup. Namun hal ini tidak berlaku untuk daerah yang sudah mempunyai Pejabat Pembuat Akta Tanah atau Pejabat Pembuat Akta Tanah Sementara.

\section{PENUTUP}

1. Status jual beli tanah tanpa menggunakan akta Pejabat Pembuat Akta Tanah menurut Putusan Mahkamah Agung Nomor: 153/PK/PDT/2005 dinyatakan sah oleh Pengadilan, tetapi Majelis Hakim tetap memerintahkan/ menghukum Penjual dan Pembeli menghadap Pejabat Pembuat Akta Tanah untuk membuat Akta Jual Beli. Jual beli yang dilakukan secara adat yang sering disebut jual beli di bawah tangan atau jual beli tanpa menggunakan akta Pejabat Pembuat Akta Tanah untuk tanah bersertifikat adalah sah tetapi tidak bisa didaftarkan pada kantor Pertanahan. Jual beli tanah adalah sah apabila semua syarat materiil dan syarat formal terpenuhi dan unsur-unsur teori kesepakatan terpenuhi. Jual beli tanah secara di bawah tangan berdampak pada pihak pembeli karena akan menimbulkan kesulitan jika akan mendaftarkannya untuk proses balik nama sertifikat, karena 
menurut Peraturan Pemerintah Nomor 24 Tahun 1997 peralihan hak atas tanah hanya dapat didaftarkan jika dibuktikan dengan akta Pejabat Pembuat Akta Tanah.

2. Peraturan Pemerintah Nomor 24 Tahun 1997 menyebutkan peralihan hak atas tanah karena jual beli hanya dapat didaftarkan jika dibuktikan dengan akta Pejabat Pembuat Akta Tanah. Kantor Pertanahan akan menolak pendaftaran peralihan hak tersebut apabila dokumen-dokumen tidak disertai dengan akta Pejabat Pembuat Akta Tanah seperti yang disebutkan dalam Peraturan Pemerintah Nomor 24 Tahun 1997 Pasal 45. Namun dalam keadaan tertentu Jual beli secara di bawah tangan atau jual beli tanpa menggunakan akta Pejabat Pembuat Akta dapat di- daftarkan ke Kantor Pertanahan, hal ini disebutkan dalam Peraturan Pemerintah nomor 24 Tahun 1997 Pasal 37 ayat 2, yang berbunyi: Dalam keadaan tertentu sebagaimana yang ditentukan oleh Menteri, Kepala Kantor Pertanahan dapat mendaftar pemindahan hak atas bidang tanah hak milik, yang dilakukan di antara perorangan warga Negara Indonesia yang dibuktikan dengan akta yang tidak dibuat oleh Pejabat Pembuat Akta Tanah, tetapi yang menurut Kepala Kantor Pertanahan tersebut kadar kebenarannya dianggap cukup untuk, mendaftar pemindahan hak yang bersangkutan 